Short Communication

\title{
Interferon-beta treated-multiple sclerosis patients exhibit a decreased ratio between immature/transitional B cell subset and plasmablasts
}

\author{
Andreia Monteiro $^{\mathrm{a}, \mathrm{b}}$, Catarina Cruto ${ }^{\mathrm{c}}$, Pedro Rosado $^{\mathrm{c}}$, Luiza Rosado ${ }^{\mathrm{a}, \mathrm{c}}$, Ana Mafalda Fonseca ${ }^{\mathrm{a}}$, \\ Artur Paiva ${ }^{\mathrm{d}, \mathrm{e}, \mathrm{f}, *}$ \\ ${ }^{a}$ Centro de Investigação em Ciências da Saúde, Universidade da Beira Interior (CICS-UBI), Avenida Infante D. Henrique, Covilhã 6200-506, Portugal \\ ${ }^{\mathrm{b}}$ Serviço Patologia Clínica, Centro Hospitalar Universitário Cova da Beira, Quinta do Alvito, 6200-251 Covilhã, Portugal \\ ${ }^{\mathrm{c}}$ Serviço de Neurologia, Centro Hospitalar Universitário Cova da Beira, Quinta do Alvito, 6200-251 Covilhã, Portugal \\ ${ }^{\mathrm{d}}$ Unidade de Gestão Operacional de Citometria, Serviço de Patologia Clínica, Centro Hospitalar e Universitário de Coimbra, Praceta Mota Pinto, 3001-301 Coimbra, \\ Portugal \\ ${ }^{\mathrm{e}}$ Coimbra Institute for Clinical and Biomedical Research (iCBR), Faculdade de Medicina, Universidade de Coimbra, Polo III - Health Sciences Campus Azinhaga Santa \\ Comba, Celas, 3000-548 Coimbra, Portugal \\ ${ }_{\mathrm{f}}^{\mathrm{f}}$ Escola Superior de Tecnologia da Saúde de Coimbra, Rua 5 de Outubro, 3046-854 Coimbra, Portugal
}

\section{A R T I C L E I N F O}

\section{Keywords:}

Relapsing-remitting multiple sclerosis

CD27

Immature/transitional B cell subset

Plasmablast

\begin{abstract}
A B S T R A C T
Our aim was to quantify circulating B cell subsets; immature/transitional, naïve, $\mathrm{CD}_{2} 7^{-}$and $\mathrm{CD}^{2} 7^{+}$memory $^{-}$ cells and plasmablasts, in relapsing-remitting multiple sclerosis patients treated with IFN- $\beta$. The most relevant findings were a significant increase of plasmablasts and a decrease of immature/transitional B cells, resulting in a decreased ratio between those cells in relapse RRMS, together with an increase of $\mathrm{CD} 27^{-}$and $\mathrm{CD}^{2} 7^{+} \mathrm{IgM}^{+}$ memory B cell subsets in both phases of the disease. These alterations point to an active B cell response, particularly in relapse, and the above referred ratio could constitute a good biomarker of relapse in patients that underwent IFN- $\beta$ treatment.
\end{abstract}

\section{Introduction}

Multiple sclerosis (MS) is an inflammatory disease of the central nervous system (CNS). The pathology of MS leads to demyelination, astrocytic and neuronal injury (Wilson, 2012). The pathogenesis is still incompletely understood, and the cause remains unknown (Bittner et al., 2017).

MS has long been considered a 'classical' T-cell-mediated autoimmune disorder. However, the involvement of the humoral immunity has always been present by intrathecal synthesis of oligoclonal bands (OCB) in the cerebrospinal fluid (CSF), but not in serum, of about $90 \%$ of relapsing-remitting (RR)MS patients (Bittner et al., 2017; Sospedra, 2018). Despite years of research, the antigen-specificity of autoreactive antibodies in MS is still not clear (Staun-Ram and Miller, 2017). OCB are the most consistent immunodiagnostic feature and hallmark immunologic finding in MS. The accumulating evidence has brought $\mathrm{B}$ cells into focus as critical players in MS pathogenesis (Disanto et al., 2012).

B cells may be observed in the healthy brain but are scarce in number and increase drastically during neuroinflammation (Blauth et al., 2015). B cells may contribute to MS pathogenesis as precursors of antibody ( $\mathrm{Ab}$ ) secreting plasma cells, as antigen presenting cells for activation of $\mathrm{T}$ cells, and as producers of cytokines with pro- or antiinflammatory properties (Lehmann-Horn et al., 2013). Because of OCB, their pathogenic function has been traditionally associated with $\mathrm{Ab}$ production.

According to phenotypic profile of B cell subsets, which also reflects their functional abilities and behavior, four major maturation-associated subsets can be identified in the human peripheral blood (PB): immature/transitional, naïve, memory and plasmablast (Perez-Andres et al., 2010). In the germinal center (GC), B cells gain CD27, a marker considered as a hallmark of memory $\mathrm{B}$ cells, and whose expression correlates with the presence of somatic mutations in immunoglobulins genes (Fecteau and Ne, 2008; Berkowska et al., 2011; García-Sanz et al., 2016). In MS memory B cells, plasmablasts, and plasma cells preferentially cross the disrupted blood brain barrier (BBB) and migrate into the CNS, where they dominate the B cell pool and exert different effector functions (Claes et al., 2015; Sospedra, 2018).

More than two decades have passed since interferon- $\beta$ (IFN- $\beta$ ) was established as the first disease-modifying therapy (DMT) found to be

\footnotetext{
* Corresponding author.

E-mail address: artur.paiva@chuc.min-saude.pt (A. Paiva).
} 
effective in the management of MS. It remains a valid approach because of its good benefit/risk profile (Rizo et al., 2016).

Recently, the introduction of B-cell-depleting therapies, which rapidly reduce B cells and eliminate their pathogenicity in MS, demonstrates a strong efficacy in RRMS, despite their inability to deplete CD20 negative circulating plasma cells. However, treated patients seemed to have stable plasma cell numbers and unchanged OCB production in the CSF. This implies that the most critical role of B cells in MS disease development could be not linked to their Ab-producing capacity, but to their role in antigen presentation and regulation of $\mathrm{T}$ cell differentiation and effector functions in the development of the autoimmune response (Ramgolam et al., 2011; Michel et al., 2015; Bittner et al., 2017; Li et al., 2018).

There are still many unresolved questions surrounding MS and the B cells in this disease. Possibly, B cells have been underestimated in the immunopathogenesis of MS. In this scenario, the aim of this work was to characterize circulating B cell subsets in remission and relapse RRMS patients treated with IFN- $\beta$ and compare to healthy controls.

\section{Material and methods}

\subsection{Patients and healthy controls}

This study enrolled 38 patients with the diagnosis of RRMS based on clinical, magnetic resonance image, and biochemical principles, according to the MacDonald criteria 2010 (Polman et al., 2011). The inclusion condition was the treatment with IFN- $\beta$. The exclusion criteria were the corticosteroid treatment, active infection, local or systemic disease affecting the immune system (neoplasia, psoriasis, chronic inflammatory, or other autoimmune diseases), pregnancy, and other treatments for MS. A relapse was defined as an acute inflammatory demyelinating event in the CNS with a duration of at least $24 \mathrm{~h}$, in the absence of fever or infection, and documented with neurological findings. Disability was scored on the Expanded Disability Status Scale (EDSS), ranging from 0 to 10 , with higher scores indicating greater disability. Patients were divided into two groups according to the phase of the disease. 30 patients in remission and 8 patients in relapse.

The group of healthy controls (HC) were composed by 20 healthy age- and gender-matched volunteers. The inclusion criteria for this group were the absence of autoimmune diseases and/or active infection and no treatment with immunomodulatory drugs. The complete demographic and clinical characteristics of patients and HC involved can be found in Table 1 .
All patients and volunteers signed an informed consent and the study was approved by the ethics committee of Centro Hospitalar Cova da Beira with number 54 .

\subsection{Immunofluorescence staining of peripheral B cell subsets}

For the identification of $\mathrm{B}$ cell subsets, the following monoclonal antibodies were added to $250 \mu \mathrm{l}$ of PB collected in K3-EDTA: CD20-PB (Pacific Blue; clone 2H7; BioLegend, San Diego, CA, USA); CD27-PC5 (phycoerythrin-cyanine 5; clone 1A4LDG5; Beckman Coulter; USA); CD19-PC7 (phycoerythrin-cyanine 7; clone J3-119; Beckman Coulter, France); CD45-KO (Krome Orange; clone J.33; Beckman Coulter, France); CD38-APC-H7 (allophycocyanin-hilite7; clone HB7; BD Biosciences, San Jose, CA, USA). The samples were then incubated for $15 \mathrm{~min}$ at room temperature and kept in the dark. To determine the immunoglobulin class, an intracytoplasmic staining was performed with the monoclonal antibodies IgG-FITC (fluorescein isothiocyanate, clone G18-145, BD Pharmingen, San Diego, CA, USA), IgA-PE (phycoerythrin, clone IS11-8E10, Macs Miltenyi Biotec, Bergisch Gladbach, Germany) and IgM-APC (allophycocyanin, clone G20-127, BD Pharmingen) using IntraPrep kit (Beckman Coulter, Brea, CA, USA) according to the supplier instructions. The cell pellet was resuspended in $0.5 \mathrm{ml}$ of phosphate buffer saline (Gibco, Paisley, Scotland). The flow cytometry gating strategy to identify circulating B cell subsets is shown in Fig. 1.

\subsection{Flow cytometry data acquisition and analysis}

Data acquisition was performed in FACSCanto ${ }^{\mathrm{TM}} \mathrm{II}$ (BD) flow cytometer equipped with FACSDiva software (version 6.1.2: BD). The number of events acquired was always above $0.5 \times 10^{6}$. For data analysis, Infinicyt (version 1.8) software (Cytognos SL, Salamanca, Spain) was used.

\subsection{Statistical analysis}

The statistical evaluation of the obtained results was done using the non-parametric Mann-Whitney $U$ test. The results were expressed as the median \pm standard deviation (SD). All statistical analyses were performed using SPSS software program (version 23.0) (IBM, Amonk, NY, USA). $p$ values $<.05$ were considered statistically significant.

Table 1

Demographic and clinical characteristics of RRMS patients and healthy controls, NA not applicable, EDSS expanded disability status scale, SI subcutaneous injection, IM intramuscular injection.

\begin{tabular}{|c|c|c|c|}
\hline & $\begin{array}{l}\mathrm{HC} \\
(n=20)\end{array}$ & $\begin{array}{l}\text { Remission RRMS } \\
(n=30)\end{array}$ & Relapse RRMS ( $n=8)$ \\
\hline Age (median \pm SD) & $48 \pm 9$ & $44 \pm 11$ & $41 \pm 10$ \\
\hline Male $(\%)$ & $20 \%$ & $10 \%$ & $37.5 \%$ \\
\hline Female $(\%)$ & $80 \%$ & $90 \%$ & $62.5 \%$ \\
\hline Leukocytes (median $\left.\pm \mathrm{SD} \times 10^{9} / 1\right)$ & $7.1 \pm 2.0$ & $6.6 \pm 2.0$ & $8.4 \pm 4.9$ \\
\hline EDSS-score (median $\pm \mathrm{SD}$ ) & NA & $1.8 \pm 1.1$ & $3 \pm 2.1$ \\
\hline Age disease of the onset (median $\pm \mathrm{SD}$ ) & NA & $32.7 \pm 9.9$ & $34.9 \pm 10.3$ \\
\hline Disease duration (median $\pm S \mathrm{SD}$, years) & NA & $11.1 \pm 8.2$ & $4.8 \pm 5.7$ \\
\hline \multicolumn{4}{|l|}{ Treatment } \\
\hline IFN-beta 1a SI $22 \mu \mathrm{g} 3 \times$ week (n) & NA & 1 & 0 \\
\hline Length of treatment (median $\pm S D$, years) & NA & 2 & 0 \\
\hline IFN-beta 1a SI $44 \mu g$ $3 \times$ week (n) & NA & 3 & 1 \\
\hline Length of treatment (median $\pm \mathrm{SD}$, years) & NA & $5.7 \pm 4.0$ & 3 \\
\hline IFN-beta 1a IM $30 \mu \mathrm{g} 1 \times$ week(n) & NA & 14 & 3 \\
\hline Length of treatment (median $\pm \mathrm{SD}$, years) & NA & $6.4 \pm 2.3$ & $9.0 \pm 4.2$ \\
\hline IFN-beta $1 \mathrm{~b}$ IM $250 \mu \mathrm{g}$ every other day (n) & NA & 10 & 4 \\
\hline Length of treatment (median $\pm S D$, years) & NA & $4.8 \pm 2.2$ & $5.7 \pm 1.2$ \\
\hline IFN-beta 1 b IM $250 \mu$ g every other day (n) & NA & 2 & 0 \\
\hline Length of treatment (median $\pm S D$, years) & NA & $4.0 \pm 1.4$ & 0 \\
\hline Untreated patients & NA & 0 & 0 \\
\hline
\end{tabular}




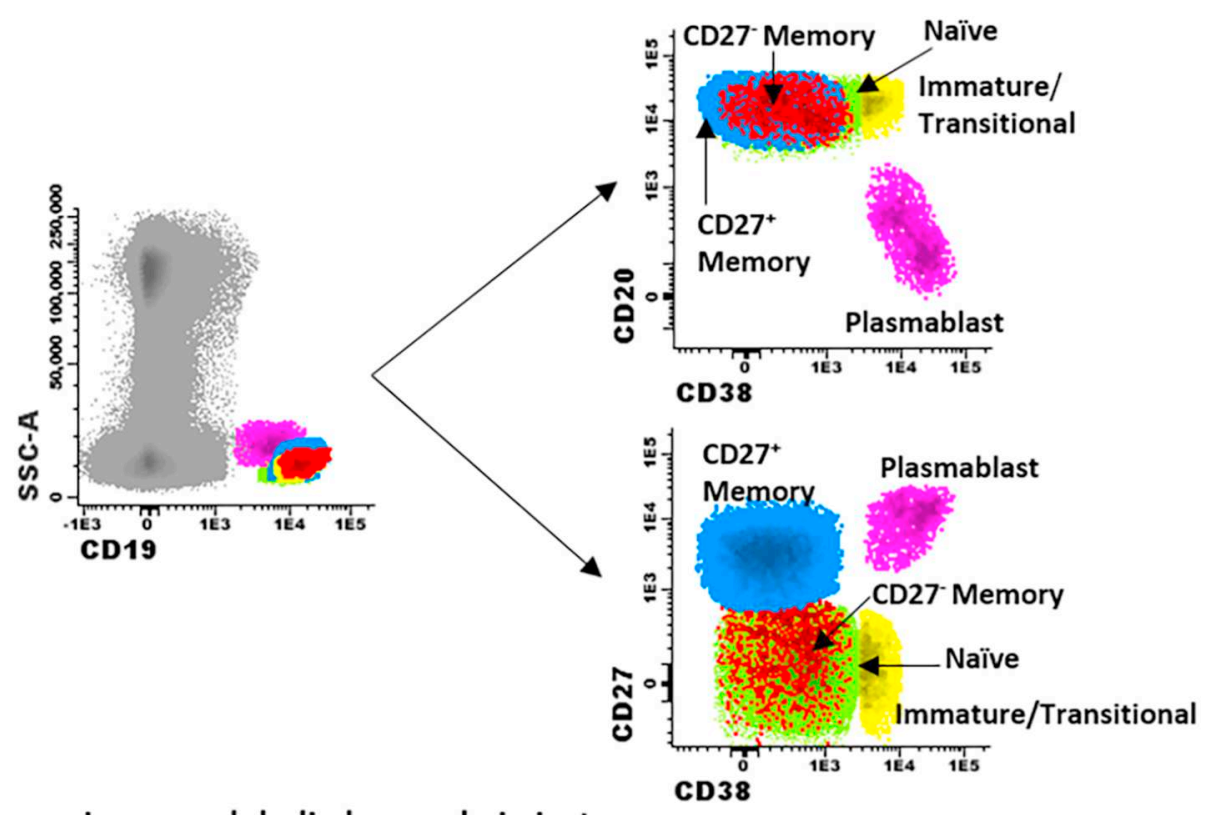

Immunoglobulin heavy chain isotypes
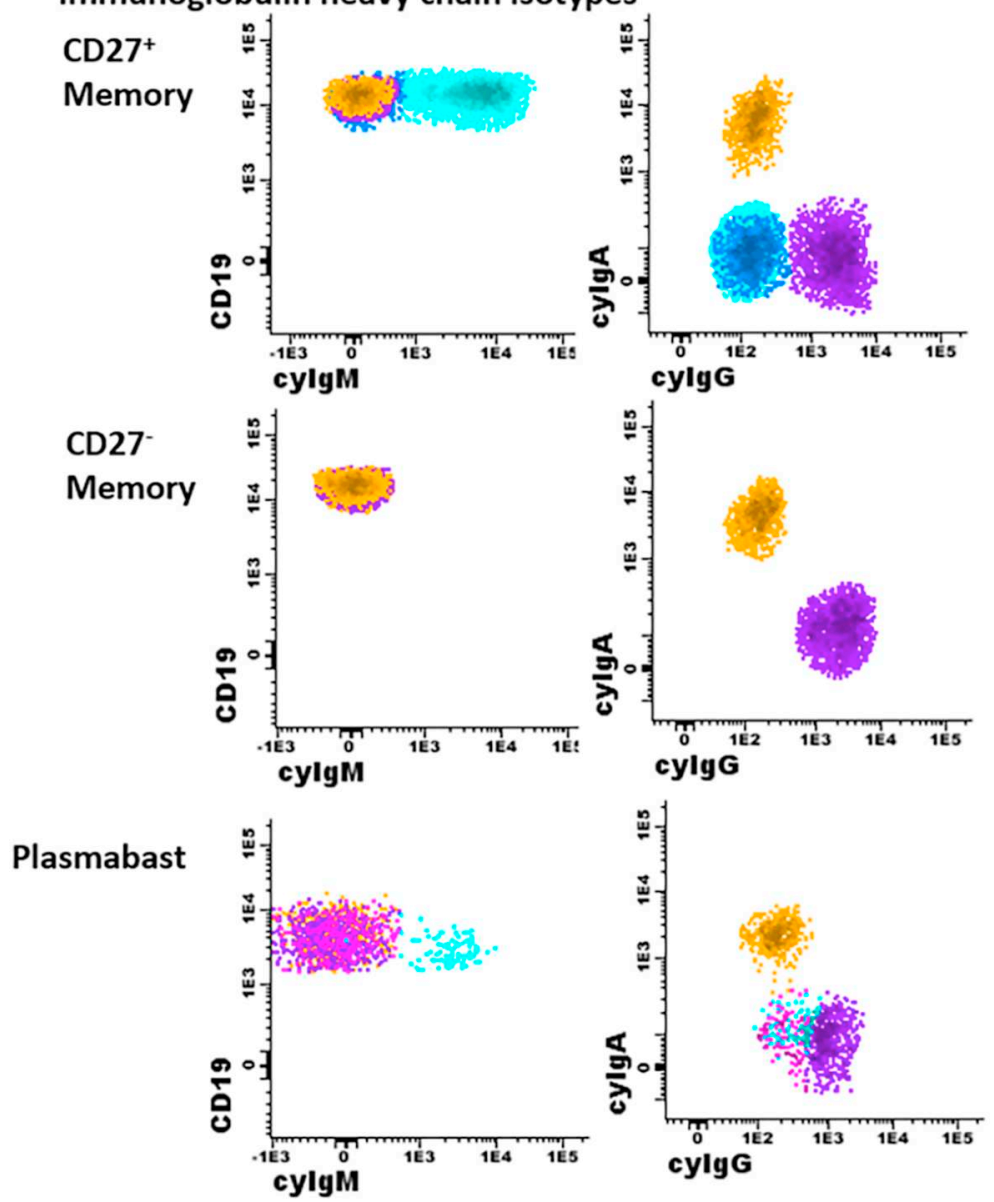

Fig. 1. Flow cytometry strategy to identify circulating B cell subsets: immature/transitional, naïve, memory and plasmablasts, and the expression of IgM, IgG and IgA in $\mathrm{CD} 27^{+}$and $\mathrm{CD} 27^{-}$memory B cell subsets and plasmablast.

\section{Results and discussion}

The participation of B cells in MS has always been supported by the presence of OCB in the CSF. Because of the good results of new therapeutics directed to B cells, the study of these lymphocytes is becoming a hot point in MS research.
IFN- $\beta$ and glatiramer acetate (GA) are the first line of DMT for RRMS. How GA therapy directly affects B cells in MS patients is still not conclusive, and most of the information comes from the experimental autoimmune encephalomyelitis model (Ireland et al., 2014). Therefore, the literature is not unanimous about the effect of GA therapy on B cells from RRMS patients. In vitro studies refer that changes in B cells in IFN- 
Table 2

Frequency and absolute value of B cell subsets in healthy controls and remission and relapse RRMS patients.

\begin{tabular}{|c|c|c|c|c|c|c|}
\hline & \multicolumn{2}{|l|}{$\mathrm{HC}$} & \multicolumn{2}{|c|}{ Remission RRMS } & \multicolumn{2}{|l|}{ Relapse RRMS } \\
\hline & $\%$ & cells $/ \mu \mathrm{l}$ & $\%$ & cells/ $\mu \mathrm{l}$ & $\%$ & cells/ $\mu \mathrm{l}$ \\
\hline B cell* & $3.2 \pm 1.6$ & $226.6 \pm 119.5$ & $3.7 \pm 2.4$ & $238.4 \pm 147.1$ & $2.5 \pm 1.0^{b}$ & $171.4 \pm 57.4^{b}$ \\
\hline Immature/transitional & $4.3 \pm 1.5$ & $9.3 \pm 5.0$ & $6.1 \pm 4.3^{\mathrm{a}}$ & $13.4 \pm 12.6$ & $4.7 \pm 2.4$ & $8.2 \pm 4.2^{b}$ \\
\hline Naïve & $70.9 \pm 14.7$ & $152.8 \pm 94.1$ & $65.3 \pm 10.2$ & $153.0 \pm 115.6$ & $58.5 \pm 12.0$ & $93.6 \pm 43.2^{b}$ \\
\hline Memory & $30.6 \pm 15.1$ & $71.9 \pm 48.9$ & $26.1 \pm 10.4$ & $57.9 \pm 35.3$ & $33.6 \pm 13.0$ & $36.8 \pm 26.5$ \\
\hline $\mathrm{CD} 7^{+}$Memory & $24.6 \pm 15.1$ & $60.0 \pm 48.9$ & $20.9 \pm 9.5$ & $37.6 \pm 25.8$ & $26.9 \pm 12.5$ & $30.9 \pm 24.2$ \\
\hline $\operatorname{IgA}$ & $14.4 \pm 4.9$ & $7.0 \pm 3.8$ & $17.0 \pm 4.3$ & $6.1 \pm 3.8$ & $12.9 \pm 3.4$ & $4.2 \pm 3.2$ \\
\hline IgG & $44.2 \pm 21.3$ & $22.0 \pm 16.0$ & $26.3 \pm 11.4^{\mathrm{a}}$ & $10.3 \pm 8.3$ & $30.6 \pm 11.7$ & $9.9 \pm 12.0$ \\
\hline $\operatorname{IgM}$ & $21.9 \pm 16.6$ & $9.1 \pm 7.2$ & $44.8 \pm 15.4^{\mathrm{a}}$ & $19.7 \pm 6.0$ & $43.6 \pm 11.5^{\mathrm{a}}$ & $13.3 \pm 10.8$ \\
\hline $\mathrm{Ig}^{-}$ & $10.9 \pm 13.2$ & $5.1 \pm 7.1$ & $5.1 \pm 8.4$ & $1.5 \pm 6.0$ & $15.4 \pm 6.1$ & $4.4 \pm 3.7$ \\
\hline CD27- Memory & $1.8 \pm 0.9$ & $3.3 \pm 1.7$ & $3.6 \pm 2.2^{\mathrm{a}}$ & $7.7 \pm 6.2^{\mathrm{a}}$ & $4.0 \pm 2.3^{\mathrm{a}}$ & $6.7 \pm 3.8$ \\
\hline IgA & $61.6 \pm 17.7$ & $1.7 \pm 1.4$ & $44.5 \pm 15.3^{\mathrm{a}}$ & $3.3 \pm 3.1$ & $41.0 \pm 22.5^{\mathrm{a}}$ & $2.7 \pm 2.3$ \\
\hline IgG & $38.4 \pm 17.8$ & $1.1 \pm 0.8$ & $55.5 \pm 15.3^{\mathrm{a}}$ & $4.1 \pm 3.9$ & $59.1 \pm 22.5^{\mathrm{a}}$ & $3.6 \pm 3.3$ \\
\hline Plasmablasts & $0.5 \pm 0.9$ & $1.2 \pm 0.9$ & $0.8 \pm 0.8$ & $2.4 \pm 1.9$ & $2.0 \pm 1.3^{\mathrm{a}}$ & $1.6 \pm 1.7$ \\
\hline $\operatorname{IgA}$ & $32.2 \pm 10.3$ & $0.3 \pm 0.4$ & $32.8 \pm 9.5$ & $0.9 \pm 0.6$ & $34.0 \pm 13.7$ & $0.7 \pm 1.0$ \\
\hline IgG & $45.3 \pm 14.2$ & $0.3 \pm 03$ & $37.4 \pm 14.5$ & $0.9 \pm 1.0$ & $27.9 \pm 11.7$ & $0.8 \pm 0.5$ \\
\hline $\operatorname{IgM}$ & $16.2 \pm 15.0$ & $0.1 \pm 0.4$ & $27.0 \pm 11.8^{\mathrm{a}}$ & $0.4 \pm 0.7$ & $25.3 \pm 9.6$ & $0.5 \pm 0.5$ \\
\hline $\mathrm{Ig}^{-}$ & $7.9 \pm 9.8$ & $0.1 \pm 0.1$ & $1.8 \pm 4.2$ & $0.1 \pm 0.1$ & $2.7 \pm 3.7$ & $0.1 \pm 0.1$ \\
\hline $\begin{array}{l}\text { Ratio (Immature/Transitional)/ } \\
\text { Plasmablasts }\end{array}$ & $9.8 \pm 7.4$ & & $8.2 \pm 13.9$ & & $2.7 \pm 3.6^{\mathrm{a}, \mathrm{b}}$ & \\
\hline
\end{tabular}

Results are expressed as median \pm standard deviation. *Number of cells from total peripheral blood lymphocytes; HC, Healthy controls, RRMS, Relapsing-remitting

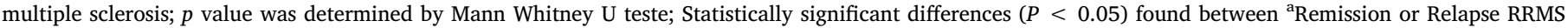
patients $v$ sC, ${ }^{\mathrm{b}}$ Remission RRMS patients $v s$ Relapse RRMS patients, marked in bold.

$\beta$ treated patients is directly due to IFN- $\beta$ treatment and not a general feature of MS disease in remission (Schubert et al. 2015). At this time, it will be impossible for us to add a new cohort of patients undergoing a different therapy. Although, a very preliminary data from our group in MS patients treated with Rituximab, an increase in plasmablasts frequency seemed to be associated to a worse response to therapy.

All the patients included were responders to the IFN- $\beta$ therapy, since the minimum of the length treatment was two years. (Table 1 ) The formulations of IFN- $\beta$ were different, however in the literature there are no differences between the effect of IFN- $\beta$ formulations on B cell subsets (Staun-Ram and Miller, 2017; Li et al., 2018; Sospedra, 2018).

In the periphery, based on surface markers, we identified the following $\mathrm{B}$ cell subsets: immature/transitional $\mathrm{CD} 19^{+} \mathrm{CD} 20^{+} \mathrm{CD} 27^{-} \mathrm{CD} 45^{+} \mathrm{CD} 38^{++}$; naive $\mathrm{CD} 19^{+} \mathrm{CD} 20^{+} \mathrm{CD} 27^{-} \mathrm{CD} 45^{+} \mathrm{CD} 38^{-}$; $\mathrm{CD} 27^{+}$memory $\mathrm{CD} 19^{+} \mathrm{CD} 20^{+}$ $\mathrm{CD} 27^{+} \mathrm{CD} 45^{+} \mathrm{CD} 38^{+ \text {low }} ; \mathrm{CD}_{2} 7^{-}$memory $\mathrm{CD} 19^{+} \mathrm{CD} 20^{+} \mathrm{CD} 27^{-} \mathrm{CD} 45^{+}$ CD38 ${ }^{+ \text {low }}$; plasmablast CD $19^{+ \text {low }} \mathrm{CD} 20^{-} \mathrm{CD} 27^{++} \mathrm{CD} 45^{+} \mathrm{CD} 38^{+ \text {high }}$ (GarcíaSanz et al., 2016; Blanco et al., 2018) (Table 2, Fig. 1). The circulation of these cells makes PB an accessible biological sample that mirrors the immune status and provides a 'window' into the immunopathogenesis of MS.

\subsection{Frequency of immature/transitional B cell subset and plasmablasts}

In remission RRMS patients the percentage of immature/transitional B cells increases (Table 2, Fig. 2). In accordance to previous reports, IFN- $\beta$ treatment increases immature/transitional B cell subset and a higher proportion of newly released B cells was found (Longbrake and Cross, 2016). This subset is able to secrete high levels of anti-inflammatory and immunomodulatory cytokine IL-10 (Staun-Ram and Miller, 2017), acting as regulatory B-cells (Perez-Andres et al., 2010). In systemic lupus erythematosus, immature/transitional B cells emerge as promising surrogate markers for disease activity (Henriques et al., 2016). In RRMS, the increase of immature/transitional B cell subset can be seen as an attempt to increase anti-inflammatory cytokines.

IFN- $\beta$ can also promote the induction of the expression of B-cell survival factor and B-cell-activating factor of the tumor necrosis factor family (BAFF). BAFF promotes the survival of B cells at and beyond the immature/transitional stage of development. Meanwhile, there was a decrease in the proportion of circulating class-switched memory B cells (Schubert et al. 2015; Longbrake and Cross, 2016).

The relapsing RRMS patients exhibited the main changes in B cell

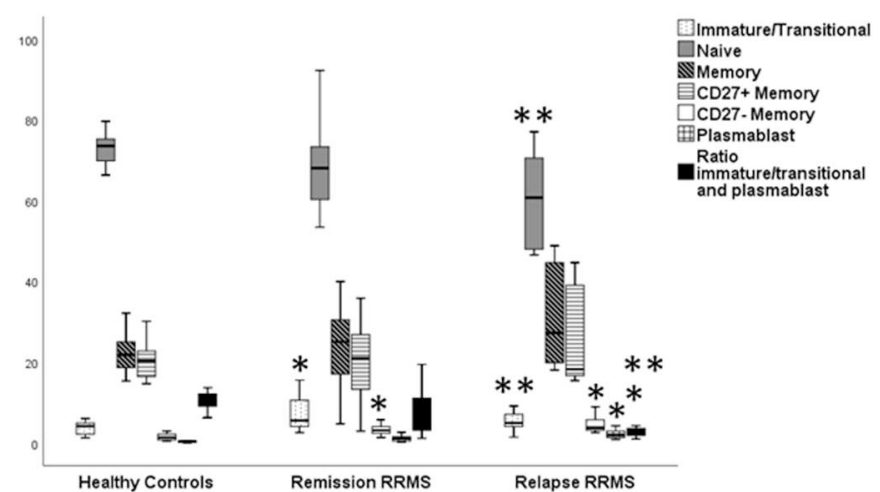

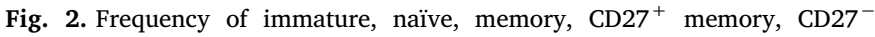
memory, plasmablasts B cell subsets and ratio between the (immature/transitional) B cells and plasmablasts, in healthy controls, in remission, and relapse RRMS patients. * Remission or relapse RRMS patient's $v s$ Healthy controls; ** Remission RRMS patients $v s$ Relapse RRMS patients, with $p<.05$.

subsets homeostasis, resulting in a decrease in the total population of $\mathrm{B}$ cells, including a decrease of the immature/transitional and naïve B cell subsets when compared with remission RRMS patients. On the other hand, the plasmablast $B$ cell subset presented an increase in relapse RRMS patients (Table 2, Fig. 2). In fact, we calculated the ratio between immature/transitional B cells and plasmablasts and observed a statistically significant decrease in relapse when compared to remission RRMS (Fig. 2). Moreover, we compared the results for these two B cell subsets in four patients at both disease phases and in all of them we observed a decreased frequency of immature/transitional B cells and an increased frequency of plasmablasts in relapse (Fig. 3 A,B,C).

Despite the CNS has been traditionally considered immunologically privileged there are growing evidences suggesting that $\mathrm{B}$ cells are able to travel back and forth across the BBB and commonly reenter GC (in the meninges or cervical lymph nodes) to undergo further somatic hypermutations (Bittner et al., 2017; Li et al., 2018). A bidirectional exchange across the BBB was supported by recent somatic hypermutation studies indicating that B cells identify their specific antigen in the CNS and can undergo affinity maturation (Staun-Ram and Miller, 2017; Eggers et al., 2017). These new and recent data may lead us to suppose 


\section{Immature/transitional B cell subset and plasmablast in remission vs relapse RRMS patients}
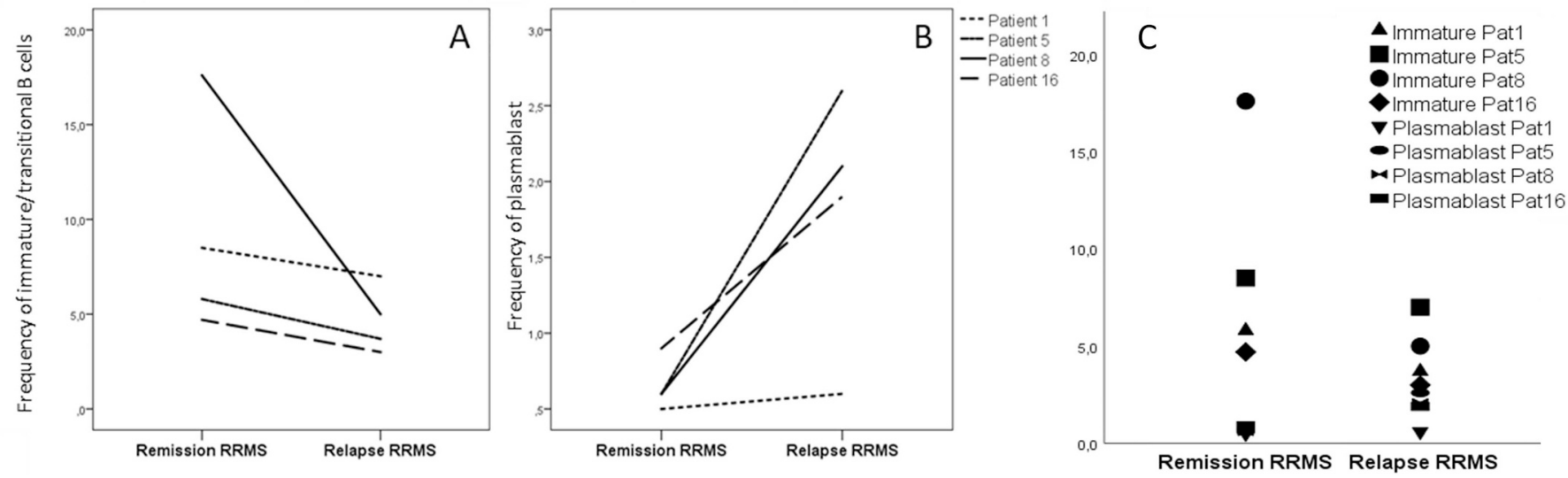

Fig. 3. Frequency of (A) immature/transitional B cell subset and (B) plasmablasts (C) dispersion graph of immature/ transitional and plasmablast B cell subset, in patient 1, 5, 8, 16 in remission and relapse phase of RRMS.

that the increase of plasmablasts in circulation of relapsing episodes may also be due to a migration of these cells from cervical lymph nodes and/or from B cell aggregates described in the meninges of MS patients to the BM in an attempt to promote the immune response (Mitsdoerffer and Peters, 2016).

\subsection{Memory B cell subsets}

The human memory B-cell compartment is more complex than originally thought based on their antigen-experienced phenotype and differential expression of CD27 and immunoglobulin heavy chain isotypes. Though CD27 is a hallmark of memory B cells, CD27- memory B cells had been identified, namely $\mathrm{CD}_{27}^{-} \mathrm{IgG}^{+}$and $\mathrm{CD}^{2} 7^{-} \mathrm{IgA}^{+}$classswitched B cells (Fecteau et al., 2006; Wei et al., 2007; Berkowska et al., 2011; Centuori et al., 2018).

Concerning memory $\mathrm{B}$ cell subsets there is an increase of $\mathrm{CD}_{27}^{+} \mathrm{IgM}^{+}$and $\mathrm{CD}^{+} 7^{-} \mathrm{IgG}^{+}$cells, accompanied by a decrease of $\mathrm{CD}^{2} 7^{-} \mathrm{IgA}^{+}$, in both groups of RRMS patients. Several studies have already shown an expansion of $\mathrm{CD}_{27}{ }^{+} \mathrm{IgM}^{+}$and $\mathrm{CD}^{2} 7^{-} \mathrm{IgG}^{+}$memory B cell subsets in autoimmune diseases (Wei et al., 2007; Perez-Andres et al., 2010; Berkowska et al., 2011).

In vitro treatment of B cells with IFN- $\beta$ inhibits B cells' stimulatory capacity by reducing CD40 and CD80 expression, for both RRMS patients and healthy controls (Staun-Ram and Miller, 2017). The strength of CD40 signaling may influence differentiation along the plasma cell versus GC B-cell pathway. In the absence of CD40, GC formation is avoided and $\mathrm{Ab}$ responses are largely limited to low-affinity IgM (Rickert et al., 2011). This mechanism could, at least in part, explain the increase of $\mathrm{CD}_{2} 7^{+} \mathrm{IgM}^{+}$memory B cells observed in our groups of patients, since this subset can be generated independently of a functional GC. (García-Sanz et al., 2016).

The CD27 ${ }^{-}$memory B cell subset has undergone class switching, though they do not gain the expression of CD27. Little is known about the function of these cells in immunity (Centuori et al., 2018). It is therefore tempting to postulate that $\mathrm{CD}^{-} 7^{-}$memory cells develop outside the GC in extrafollicular reactions. The absence of CD27 might impair the ability of these cells to receive the full and sustained degree of T cell help required to complete a GC reaction (Wei et al., 2007). Based on the new recirculation of $\mathrm{B}$ cells through $\mathrm{BBB}$, as already described, $\mathrm{CD}_{27}{ }^{-} \mathrm{IgG}^{+}$memory B cell subset may be originated in CNS, more exactly in the B cell aggregates described in the meninges of MS patients (Mitsdoerffer and Peters, 2016).

\section{Conclusion}

In conclusion it was seen that participation of B cells in RRMS goes far beyond antibody production alone. Recent data from a bidirectional exchange of B cells through BBB makes the study of B cell subsets even more relevant to be useful for monitoring the disease activity in RRMS patients.

In fact, not only RRMS patients exhibited increased frequencies of $\mathrm{CD}_{27}{ }^{+} \mathrm{IgM}^{+}$and $\mathrm{CD} 27^{-} \mathrm{IgG}^{+}$memory B cells, but also relapse patients had increased levels of plasmablasts that, together with a decrease of immature/transitional B cells, induce a significant decrease in the ratio of this two B cell subsets. Thus, this ratio could constitute a good biomarker to monitor response to therapy that could be relevant in B cell depletion in monoclonal antibodies-based therapy.

\section{Acknowledgements}

This work is supported by FEDER funds through the POCI COMPETE 2020 - Operational Programme Competitiveness and Internationalisation in Axis I - Strengthening research, technological development and innovation (Project POCI-01-0145-FEDER-007491) and National Funds by FCT - Foundation for Science and Technology (Project UID/Multi/00709/2013).

\section{References}

Berkowska, M. a, Driessen, G.J. a, Bikos, V., Grosserichter-Wagener, C., Cerutti, A., He, B., Biermann, K., Lange, J.F., Van Der Burg, M., Grosserichter-, C., 2011. Human memory B cells originate from three distinct germinal center-dependent and -independent maturation pathways Human memory B cells originate from three distinct germinal center- dependent and -independent maturation pathways. Blood 118, 2150-2159. https://doi.org/10.1182/blood-2011-04-345579.

Bittner, S., Ruck, T., Wiendl, H., Grauer, O.M., Meuth, S.G., 2017. Targeting B cells in relapsing-remitting multiple sclerosis: from pathophysiology to optimal clinical management. Ther. Adv. Neurol. Disord. 10, 51-66. https://doi.org/10.1177/ 1756285616666741.

Blanco, E., Pérez-Andrés, M., Arriba-Méndez, S., Contreras-Sanfeliciano, T., Criado, I., Pelak, O., Serra-Caetano, A., Romero, A., Puig, N., Remesal, A., Torres Canizales, J., López-Granados, E., Kalina, T., Sousa, A.E., van Zelm, M., van der Burg, M., van Dongen, J.J.M., Orfao, A., 2018. Age-associated distribution of normal B-cell and plasma cell subsets in peripheral blood. J. Allergy Clin. Immunol. 141, 2208-2219.e16. https://doi.org/10.1016/j.jaci.2018.02.017.

Blauth, K., Owens, G.P., Bennett, J.L., 2015. The ins and outs of B cells in multiple sclerosis. Front. Immunol. 6, 1-7. https://doi.org/10.3389/fimmu.2015.00565.

Centuori, S.M., Gomes, C.J., Kim, S.S., Putnam, C.W., Larsen, B.T., Garland, L.L., Mount, D.W., Martinez, J.D., 2018. Double-negative (CD27-IgD-) B cells are expanded in NSCLC and inversely correlate with affinity-matured B cell populations. J. Transl. Med. 16, 1-8. https://doi.org/10.1186/s12967-018-1404-z. 
Claes, N., Fraussen, J., Stinissen, P., Hupperts, R., Somers, V., 2015. B cells are multifunctional players in multiple sclerosis pathogenesis: Insights from therapeutic interventions. Front. Immunol. 6. https://doi.org/10.3389/fimmu.2015.00642.

Disanto, G., Morahan, J.M., Barnett, M.H., Giovannoni, G., Ramagopalan, S.V., 2012. The evidence for a role of B cells in multiple sclerosis. Neurology 78, 823-832. https:// doi.org/10.1212/WNL.0b013e318249f6f0.

Eggers, E.L., Michel, B.A., Wu, H., Wang, S., Bevan, C.J., Abounasr, A., Pierson, N.S., Bischof, A., Kazer, M., Leitner, E., Greenfield, A.L., Demuth, S., Wilson, M.R., Henry, R.G., Cree, B.A.C., Hauser, S.L., von Büdingen, H.-C., 2017. Clonal relationships of CSF B cells in treatment-naive multiple sclerosis patients. JCI Insight 2, 1-16. https:// doi.org/10.1172/jci.insight.92724.

Fecteau, J.F., Côté, G., Néron, S., 2016. A New Memory CD27 \% IgG \% B Cell Population in Peripheral Blood Expressing V H Genes with Low Frequency of Somatic Mutation 1. J. Immunol. 177 (6), 3728-3736. https://doi.org/10.4049/jimmunol.177.6.3728.

García-Sanz, R., Jiménez, C., Puig, N., Paiva, B., Gutiérrez, N.C., Rodríguez-Otero, P., Almeida, J., San Miguel, J., Orfão, A., González, M., Pérez-Andrés, M., 2016. Origin of Waldenstrom's macroglobulinaemia. Best Pract. Res. Clin. Haematol. 29, 136-147. https://doi.org/10.1016/j.beha.2016.08.024.

Henriques, A., Silva, I., Inês, L., Souto-Carneiro, M.M., Pais, M.L., Trindade, H., da Silva, J.A.P., Paiva, A., 2016. CD38, CD81 and BAFFR combined expression by transitional B cells distinguishes active from inactive systemic lupus erythematosus. Clin. Exp. Med. 16, 227-232. https://doi.org/10.1007/s10238-015-0348-3.

Ireland, S.J., Guzman, A.A., O'Brien, D.E., Hughes, S., Greenberg, B., Flores, A., Graves, D., Remington, G., Frohman, E.M., Davis, L.S., Monson, N.L., 2014. The effect of glatiramer acetate therapy on functional properties of B cells from patients with relapsing-remitting multiple sclerosis. JAMA Neurol. 71, 1421-1428. https://doi.org/ 10.1001/jamaneurol.2014.1472.

Lehmann-Horn, K., Kronsbein, H.C., Weber, M.S., 2013. Targeting B cells in the treatment of multiple sclerosis: recent advances and remaining challenges. Ther. Adv. Neurol. Disord. 6, 161-173. https://doi.org/10.1177/1756285612474333.

Li, R., Patterson, K.R., Bar-Or, A., 2018. Reassessing B cell contributions in multiple sclerosis. Nat. Immunol. 19, 696-707. https://doi.org/10.1038/s41590-018-0135-x.

Longbrake, E.E., Cross, A.H., 2016. Effect of Multiple Sclerosis Disease-Modifying Therapies on B Cells and Humoral Immunity. pp. 8. https://doi.org/10.1001/ jamaneurol.2015.3977.

Michel, L., Touil, H., Pikor, N.B., Gommerman, J.L., Prat, A., Bar-Or, A., 2015. B cells in the multiple sclerosis central nervous system: trafficking and contribution to CNScompartmentalized inflammation. Front. Immunol. 6, 1-12. https://doi.org/10. 3389/fimmu.2015.00636.

Mitsdoerffer, M., Peters, A., 2016. Tertiary lymphoid organs in central nervous system autoimmunity. Front. Immunol. 7, 1-12. https://doi.org/10.3389/fimmu.2016. 00451.

Perez-Andres, M., Paiva, B., Nieto, W.G., Caraux, A., Schmitz, A., Almeida, J., Vogt, R.F., Marti, G.E., Rawstron, A.C., Van Zelm, M.C., Van Dongen, J.J.M., Johnsen, H.E., Klein, B., Orfao, A., 2010. Human peripheral blood B-Cell compartments: a crossroad in B-cell traffic. Cytom. Part B - Clin. Cytom. 78, 47-60. https://doi.org/10.1002/ cyto.b. 20547.

Polman, C.H., Reingold, S.C., Banwell, B., Clanet, M., Cohen, J.A., Filippi, M., Fujihara, K., Havrdova, E., Hutchinson, M., Kappos, L., Lublin, F.D., Montalban, X., O'Connor, P., Sandberg-Wollheim, M., Thompson, A.J., Waubant, E., Weinshenker, B., Wolinsky, J.S., 2011. Diagnostic criteria for multiple sclerosis: 2010 Revisions to the McDonald criteria. Ann. Neurol. 69, 292-302. https://doi.org/10.1002/ana.22366.

Ramgolam, V.S., Sha, Y., Marcus, K.L., Choudhary, N., Troiani, L., Chopra, M., MarkovicPlese, S., 2011. B Cells as a Therapeutic Target for IFN- in Relapsing-Remitting Multiple Sclerosis. J. Immunol. 186, 4518-4526. https://doi.org/10.4049/jimmunol. 1000271.

Rickert, R.C., Jellusova, J., Miletic, A.V., 2011. Signaling by the tumor necrosis factor receptor superfamily in B-cell biology and disease. Immunol. Rev. 244, 115-133. https://doi.org/10.1111/j.1600-065X.2011.01067.x.

Rizo, F., Giacomini, E., Mechelli, R., Buscarinu, C., Salvetti, M., Severa, M., Coccia, R. Mechelli, R., Mechelli, E.M., 2016. Interferon-b therapy specifically reduces pathogenic memory B cells in Multiple Sclerosis patients by inducing a FAS-mediated apoptosis. Immunol. Cell Biol. https://doi.org/10.1038/icb.2016.55. (accepted article preview 6 June 2016).

Schubert, R., Hu, Y., Kumar, G., Szeto, S., Abraham, P., Winderl, J., Guthridge, J., Pardo, G., Dunn, J., Steinman, L., Axtell, R., 2015. Interferon- $\beta$ treatment requires B cells for efficacy in neuroautoimmunity. J. Immunol. 194 (5), 2110-2116. https://doi.org/10. 4049/jimmunol.1402029.

Sospedra, M., 2018. B cells in multiple sclerosis. Curr. Opin. Neurol. 31, 256-262. https:// doi.org/10.1097/WCO.000000000000563.

Staun-Ram, E., Miller, A., 2017. Effector and regulatory B cells in Multiple Sclerosis. Clin. Immunol. 184, 11-25. https://doi.org/10.1016/j.clim.2017.04.014.

Wei, C., Anolik, J., Cappione, A., Zheng, B., Pugh-Bernard, A., Brooks, J., Lee, E.-H., Milner, E.C.B., Sanz, I., 2007. A New Population of Cells Lacking Expression of CD27 Represents a Notable Component of the B Cell memory Compartment in Systemic Lupus Erythematosus. J. Immunol. 178, 6624-6633. https://doi.org/10.4049/ jimmunol.178.10.6624.

Wilson, H.L., 2012. B cells contribute to MS pathogenesis through antibody-dependent and antibody-independent mechanisms. Biol. Targets Ther. 6, 117-123. https://doi. org/10.2147/BTT.S24734. 